\title{
Subgenotype and Genetic Variability in the Precore/Core Regions of Hepatitis B Virus in Korean Patients with Chronic Liver Disease
}

\author{
Kwang Soo Lyoo Sung Woo Hong Myeong Jun Song Wonhee Hur \\ Jung Eun Choi Lian-Shu Piao Jeong Won Jang Si Hyun Bae \\ Jong Young Choi Jung Wha Park Sang Wook Choi Seung Kew Yoon \\ Department of Internal Medicine and WHO Collaborating Center on Viral Hepatitis, College of Medicine, \\ The Catholic University of Korea, Seoul, Korea
}

\section{Key Words}

Hepatitis B virus • Phylogenetic analysis • C2 subgenotype • Precore/core region · Korea

\begin{abstract}
Objective: The aim of this study was to determine the prevalence of hepatitis B virus (HBV) subgenotypes, the spectrum of mutations in the precore/core region through phylogenetic analysis, and the relevance of viral characteristics in disease progression in Korean patients. Methods: 133 patients with chronic HBV infection were enrolled. The precore and core region of HBV was amplified and sequenced. Phylogenetic analysis was performed for subgenotyping and the changes of nucleotides and amino acid were compared in liver disease stages. Results: HBV/C2 subgenotype was predominant in chronic HBV carriers (98.5\%), followed by HBV/A2 (0.75\%) and HBV/C7 (0.75\%). The mutations of the precore region were not different between liver disease stages. However, amino acid changes in the cytotoxic T lymphocyte epitope $(p<0.020)$, CD4+ T cell epitope $(p<0.027)$, or B cell epitope $(p<0.029)$ were significantly higher in liver cirrhosis patients than in chronic hepatitis patients, but not in hepatocellular carcinoma patients. Conclusion: HBV/C2 is
\end{abstract}

\section{KARGER}

Fax +4161306 1234

E-Mail karger@karger.ch

www.karger.com
(C) 2011 S. Karger AG, Basel

$0300-5526 / 11 / 0546-0333 \$ 38.00 / 0$

Accessible online at:

www.karger.com/int the most prevalent subgenotype in Korea, and HBV/C7 subgenotype found in the Philippines was first identified in the Korean population. Mutations in immune epitopes within the core gene were significantly associated with disease progression.

Copyright $\odot 2011$ S. Karger AG, Basel

Hepatitis B virus (HBV) has been classified into at least eight major genotypes (A to $\mathrm{H}$ ), and these genotypes have been further divided into subgenotypes on the basis of a $>4$ but $<8 \%$ difference in the complete nucleotide sequence [1]. The subgenotypes of $\mathrm{HBV} / \mathrm{C}$ are geographically distributed in Asian countries with C1 in Thailand and Vietnam, and C2 in Japan, China, and Korea. Subgenotypes C5, C6 and C7 were recently identified in the Philippines, Papua, and Indonesia [2-4]. In particular, genotype $\mathrm{C}$ has been reported to be linked to a more aggressive disease course and a lower rate of response to antiviral therapy compared with genotype B [5]. However, recent studies regarding the clinical rele-

K.S. Lyoo and S.W. Hong contributed equally to this study. 
Table 1. Baseline characteristics of 133 patients with chronic HBV infection

\begin{tabular}{|c|c|c|c|c|}
\hline & $\mathrm{CH}(\mathrm{n}=49)$ & $\mathrm{LC}(\mathrm{n}=43)$ & $\operatorname{HCC}(n=41)$ & $\mathrm{p}$ value \\
\hline \multicolumn{5}{|l|}{ Sex } \\
\hline $\mathrm{M}$ & $37(75.5 \%)$ & $25(58.1 \%)$ & $30(73.2 \%)$ & NS \\
\hline $\mathrm{F}$ & $12(24.5 \%)$ & $18(41.9 \%)$ & $11(26.8 \%)$ & NS \\
\hline Age, years & $35.2 \pm 12.7^{\mathrm{a}}$ & $49.3 \pm 9.3$ & $50.6 \pm 8.5$ & $<0.01$ \\
\hline HBeAg positive & $37(75.5 \%)$ & $19(44.2 \%)^{\mathrm{b}}$ & $25(61.0 \%)$ & $<0.002$ \\
\hline Anti-HBe positive & $9(18 \%)$ & $22(51 \%)^{b}$ & $14(34 \%)$ & $<0.001$ \\
\hline Anti-HBs positive & $2(4 \%)$ & $6(14 \%)$ & $3(7 \%)$ & NS \\
\hline Viral load $\pm S D$, log copies $/ \mathrm{ml}$ & $6.8 \pm 4.4^{\mathrm{a}}$ & $5.6 \pm 3.9$ & $5.3 \pm 4.1$ & $<0.009$ \\
\hline AST, U/l & $96.9 \pm 110.4$ & $62.0 \pm 60.2$ & $99.4 \pm 77.9$ & NS \\
\hline $\mathrm{ALT}, \mathrm{U} / \mathrm{l}$ & $143.6 \pm 126.4$ & $60.0 \pm 71.8$ & $101.5 \pm 141.3$ & NS \\
\hline
\end{tabular}

NS = Nonsignificant, ${ }^{\mathrm{a}} \mathrm{CH}$ vs. $\mathrm{LC}$ and HCC; ${ }^{\mathrm{L}} \mathrm{LC}$ vs. $\mathrm{CH}$.

vance of HBV subgenotypes in the development of hepatocellular carcinoma (HCC) have shown contradictory results [6-8]. Thus, the clinical significance of different HBV subgenotypes of the same genotype remains unclear. In South Korea, a very limited study on the HBV subgenotype has been done. So far, a few studies have been reported to determine the prevalence of HBV subgenotypes and viral mutations within a specific subtype [9-11].

Previous studies have shown that HBV core gene mutation frequency may be associated with clinical features of hepatitis and the severity of chronic liver disease, and $\mathrm{HBV}$ core antigen is the principle target for immune responses [12-14]. Furthermore, a mutation in the HBV core gene was reported to be involved with viral evasion from immune clearance by cellular immune response [15]. The aim of this study was to determine the prevalence of HBV subgenotypes and the spectrum of mutations in the HBV precore/core region through phylogenetic analysis and to assess the efforts that the different HBV subgenotypes and mutations exert on clinical outcomes in HBV-infected Korean patients.

A total of 133 patients with chronic HBV infection were enrolled between 2003 and 2009 from the liver clinic of the Seoul St. Mary's Hospital in South Korea. All were positive for hepatitis B surface antigen (HBsAg) for more than 6 months and seronegative for hepatitis $C$ virus (HCV). They also had no history of drug abuse or heavy alcohol consumption and serological evidence of suggestive autoimmune hepatitis, primary biliary cirrhosis, or hemochromatosis. Patients were assigned to three groups based on their clinical stage of liver disease: (1) 49 patients were histologically confirmed chronic hepatitis (CH); (2) 43 patients were diagnosed with liver cirrhosis (LC) based on clinical, hematologic, biochemical, and ultrasound criteria, and (3) 41 patients had surgically confirmed HCC, 28 with cirrhosis and 13 without. The study protocol was reviewed and approved by the Ethics Committee at the Seoul St. Mary's Hospital and informed consent was obtained from each patient prior to the study.

Serological markers of hepatitis virus infection, such as $\mathrm{HBsAg}$, anti-HBs, $\mathrm{HBeAg}$, anti-HBe and anti-HCV were tested using commercially available kits (Abbott Laboratories, Chicago, Ill., USA). The viral DNA was extracted from serum using QIAamp DNA mini and blood kit (Qiagen, Valencia, Calif., USA) according to the manufacturer's protocol. HBV precore/core gene was amplified using the nested PCR method, using primers $\mathrm{HBC} 1$ and $\mathrm{HBC} 2$ for the first round and primers $\mathrm{HBC} 3$ and $\mathrm{HBC} 4$ for the second round, as described previously [16]. For the complete genome sequencing of a few samples, another nested PCR was performed to amplify overlapping fragments of the HBV genome with several primer sets, as described previously [17].

PCR products were purified using QIAquick Gel Extraction Kit (Qiagen) according to the manufacturer's protocol, and were sequenced directly using the ABI Prism Big Dye version 3.0 kit (Applied Biosystems, Foster City, Calif., USA) on an ABI 3730XL DNA automated sequencer (Applied Biosystems). Analysis of nucleotide sequences and amino acid sequences in the precore/core of all HBV/C isolates were performed using BLAST/ Align (bl2seq) on the NCBI website and the MEGA (version 4.1) program. Nucleotide and amino acid changes in each sample were compared with the sequence of a pro- 
totype virus in Korea [18]. Mutations in B cell, CD4+ helper T cell, and cytotoxic T lymphocyte (CTL) epitopes of hepatitis B core antigen (HBcAg), as described separately in a previous study, were defined for each liver disease stage group [15]. Nucleotide sequences of precore/ core gene and the complete genome of $\mathrm{HBV}$ isolates were aligned using ClustalX (version 1.81) software and phylogenetic trees were constructed by the neighbor-joining method with other HBV reference strains from GenBank. The phylogenetic distances were calculated by bootstrapping with 1,000 repeats and molecular evolutionary analysis was performed using the MEGA (ver.4.1) program.

Data were analyzed statistically using the $\chi^{2}$ test and ANOVA, where appropriate. Multivariate analysis with logistic regression was used to determine independent factors related to the clinical development of $\mathrm{CH}, \mathrm{LC}$, and HCC. Differences between groups were compared, and $\mathrm{p}<0.05$ was deemed to indicate statistical significance.

No significant difference was observed among the three clinical statuses with respect to sex, AST, ALT, or anti-HBs positive; however, mean age and mean HBV DNA level of $\mathrm{CH}$ patients were significantly younger and higher than the patients who had LC and HCC $(\mathrm{p}<0.01$ and $\mathrm{p}<0.009$, respectively). The rates of $\mathrm{HBeAg}$ positivity and anti-HBe positivity were significantly higher and lower, respectively, in patients with $\mathrm{CH}$ than in those with LC $(\mathrm{p}<0.002)$ (table 1$)$.

$\mathrm{HBV}$ precore/core sequences of all 133 isolates were compared with those from other reference HBV strains of A-H genotypes and subgenotypes by phylogenetic analysis (fig. 1). 131 isolates (98.5\%) were designated as HBV subgenotype C2, whereas only CMC25B (GU827640) and CMC107L (GU721029) belonged to subgenotype 'A2' and 'C7', respectively. To confirm detection of the HBV/ C7 subgenotype, the complete genome of the isolate was sequenced. The alignment data showed that the isolated sequences corresponded most closely to that of the C7 reference strain (EU670263).

Two isolates, CMC67H and CMC91L, showed inframe deletion of identical lengths (87 bp; nt 2137-2223), which overlapped the $\mathrm{P}$ and core gene sequences. For comparison of nucleotide and amino acid sequences of the complete precore/core region, $129 \mathrm{HBV} / \mathrm{C} 2$ subgenotype isolates without the above 2 deleted isolates were separately analyzed by each of the disease stage group, and the genetic divergences are shown in table 2. Nucleotide and amino acid change rates in isolates from LC patients were significantly higher $(\mathrm{p}<0.02)$ than in those from $\mathrm{CH}$ patients. Amino acid changes in the core gene

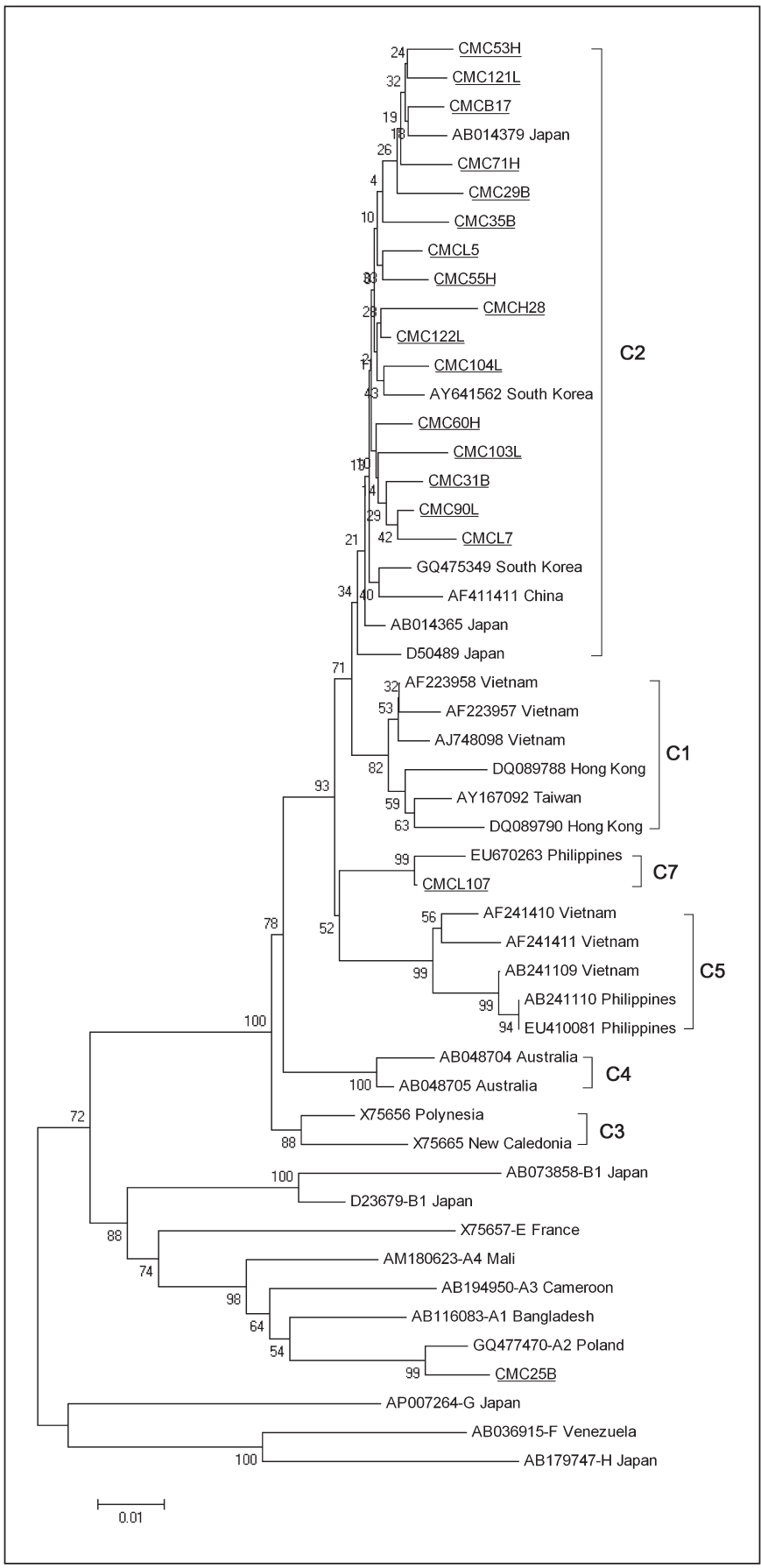

Fig. 1. Phylogenetic tree constructed based on the precore/core region using $\mathrm{A} 2, \mathrm{C} 7$, and randomly selected $\mathrm{HBV} / \mathrm{C} 2$ isolates in this study and reference strains (genotypes A to $\mathrm{H}$ ) in other phylogenetic studies. The GenBank accession numbers for the reference strains are indicated, and the isolates detected in this study are underlined (code: CMC). The alignment was analyzed by 1,000 bootstrapping replicates using the neighborhood-joining method in MEGA version 4. 
Table 2. Mean number of nucleotides and amino acid changes/patient with HBV/C2 in different stages of liver diseases

\begin{tabular}{lllll}
\hline & $\mathrm{CH}(\mathrm{n}=48)$ & LC $(\mathrm{n}=41)$ & HCC $(\mathrm{n}=40)$ & p value \\
\hline Mean nucleotide change (nt;1901-2452) & $2.06 \pm 0.7^{\mathrm{a}}$ & $2.75 \pm 0.8$ & $2.28 \pm 0.5$ & $<0.007$ \\
Mean amino acid change (AA; 1-183) & $2.90 \pm 3.1^{\mathrm{a}}$ & $3.26 \pm 2.5$ & $3.02 \pm 2.3$ & $<0.024$ \\
\hline
\end{tabular}

${ }^{\text {a }} \mathrm{CH}$ vs. $\mathrm{LC} . \mathrm{AA}=$ Amino acid codons.

Table 3. Distribution of patients who had HBV/C2 and amino acid change on immune epitopes in the core gene by different stages of liver diseases

\begin{tabular}{lllll}
\hline & CH $(\mathrm{n}=48)$ & LC $(\mathrm{n}=41)$ & HCC $(\mathrm{n}=40)$ & p value \\
\hline CTL epitope (\%) (AA; 18-27, 141-151) & $12(25)^{\mathrm{a}}$ & $20(48.7)$ & $13(32.5)$ & $<0.020$ \\
CD4+ epitope (\%) (AA; 1-20, 50-69, 117-131) & $18(37.5)^{\mathrm{a}}$ & $25(61.0)$ & $22(55.0)$ & $<0.027$ \\
B-cell epitope (\%) (AA; 74-89, 107-118, 130-138) & $23(47.9)^{\mathrm{a}}$ & $29(70.7)$ & $26(65.0)$ & $<0.029$ \\
\hline
\end{tabular}

${ }^{\text {a }} \mathrm{CH}$ vs. $\mathrm{LC} . \mathrm{CTL}=$ Cytotoxic $\mathrm{T}$ lymphocyte; $\mathrm{AA}=$ amino acid codons.

encoding $\mathrm{T}$ and $\mathrm{B}$ cell epitopes of HBcAg are shown in table 3. The amino acid changes in CTL epitope $(\mathrm{p}<$ $0.020), \mathrm{CD} 4+\mathrm{T}$ cell epitope ( $<<0.027)$, and B cell epitope $(\mathrm{p}<0.029)$ were significantly higher in LC patients than that in $\mathrm{CH}$ patients, but not in HCC patients.

The present study demonstrates that HBV/C2 (98\%) is the predominant HBV subgenotype among chronic HBV carriers in Korea. This result is consistent with previous reports from Korea $[9,10]$; however, a novel HBV isolate, identified as HBV/C7 in the Philippines [19], was first detected in Korea in this study. Cavinta et al. [19] suggested that the $\mathrm{HBV} / \mathrm{C} 7$ strain in the Philippines could have evolved from HBV subgenotype $\mathrm{C} 2$ by a new genetic mechanism. However, it is unclear whether the novel HBV/C7 isolate described here also evolved from the C2 subgenotype in Korea, or if the strain was transported by the patient from the Philippines. This should be investigated further. Interestingly, only 1 patient of 133 with chronic HBV infection had HBV genotype A2 which is known to be a very rare strain in Korea. In this study, subgenotyping was performed solely by sequencing and phylogenetic analysis of the precore/core gene. Indeed, recent studies have demonstrated that sequence analysis of the entire precore/core region produces consistent $\mathrm{HBV}$ genotyping data compared with the results of $\mathrm{P}$ gene, $\mathrm{S}$ gene, $\mathrm{X}$ gene, or even complete genome of $\operatorname{HBV}[3,16,20]$.
It is generally assumed that the genotype or subgenotype to which a viral isolate belongs could be related to the virulence and pathogenesis in patients infected with the particular virus. Genotype $\mathrm{C} \mathrm{HBV}$ has been reported to be more prevalent in patients with advanced liver diseases such as LC or liver fibrosis, and this genotype was closely associated with more severe clinical outcomes and worse prognosis during antiviral therapy compared with genotype B HBV $[5,21,22]$. However, the comparison of clinical outcomes between genotypes or subgenotypes in Korea was difficult because HBV genotype C comprised almost $100 \%$ of total HBV infections [23]. This finding may be attributable to the homologous ethnic background of the Korean population.

In the present study, mean age was significantly younger but the rate of $\mathrm{HBeAg}$ positivity was significantly higher in the $\mathrm{CH}$ group than the LC or HCC group. These results are consistent with previous results from Japan and China $[3,24,25]$. These finding might be explained that the age of the $\mathrm{CH}$ patients infected with $\mathrm{HBV}$ was relatively younger than those who were LC patients. Broadly, there are four phases in the evolution of chronic HBV infection: (1) the immune tolerant phase; (2) the immune clearance phase; (3) the low replicative phase, and (4) the reactivation phase. During the low replicative 
phase, active replication of $\mathrm{HBV}$ ceases and then $\mathrm{HBeAg}$ becomes negative.

In the past, most investigations have focused on analysis of the genetic variation of the basal core promoter and/or precore regions rather than on the core gene. The pathogenic role of core promoter (CP) mutations (T1762/ A1764) of HBV in disease progression has reported, and double CP mutations at baseline were significantly associated with the eventual development of cirrhosis or HCC [23]. However, it was assumed that the variation of the core gene or structural change of $\mathrm{HBcAg}$ may be more associated with the severity or progression of liver disease because $\mathrm{HBcAg}$ is a critical target for CTL response [15]. It was therefore suggested that the core gene mutation can alter CTL activity; this may be clinically significant, because these cells have a major role in the clearance of HBV-infected hepatocytes and are known to mediate liver damage [26]. In this study, the genetic divergence of nucleotides and amino acids in the core gene of HBV from individuals with LC was significantly higher $(p<0.02)$ than in those from patients with $\mathrm{CH}$ group. Furthermore, rates of amino acid change in CTL epitope, CD4+ T cell epitope, or B cell epitope of $\mathrm{HBcAg}$ of $\mathrm{HBV} / \mathrm{C}$ isolates were significantly higher in advanced liver diseases (e.g. LC) than in those in the $\mathrm{CH}$ group, suggesting that mutations in these immune eitopes in the core gene may be related to chronic disease progression. However, no significance was observed in these changes of immune epitopes of the core gene between the $\mathrm{CH}$ and HCC groups. This may explain why some patients with HCC have no evidence of liver cirrhosis which is required over a long period of time. Thus, these findings suggest that due to implications for clinical progression and disease severity, continuous surveillance for genetic variation of $\mathrm{HBV}$ core region may be valuable.

\section{Acknowledgement}

This research was supported by the Bio R\&D program through the National Research Foundation of Korea funded by the Ministry of Education, Science and Technology (2010-0018167).

\section{References}

1 Kramvis A, Kew M, Francois G: Hepatitis B virus genotypes. Vaccine 2005;23:24092423.

2 Mulyanto, Depamede SN, Surayah K, Tsuda F, Ichiyama K, Takahashi M, Okamoto H: A nationwide molecular epidemiological study on hepatitis B virus in Indonesia: identification of two novel subgenotypes, B8 and C7. Arch Virol 2009;154:1047-1059.

-3 Sakamoto T, Tanaka Y, Orito E, Co J, Clavio J, Sugauchi F, Ito K, Ozasa A, Quino A, Ueda R, Sollano J, Mizokami M: Novel subtypes (subgenotypes) of hepatitis B virus genotypes $\mathrm{B}$ and $\mathrm{C}$ among chronic liver disease patients in the Philippines. J Gen Virol 2006; 87:1873-1882.

4 Utsumi T, Lusida MI, Yano Y, Nugrahaputra VE, Amin M, Juniastuti, Soetjipto, Hayashi $\mathrm{Y}$, Hotta $\mathrm{H}$ : Complete genome sequence and phylogenetic relatedness of hepatitis B virus isolates in Papua, Indonesia. J Clin Microbiol 2009; 47:1842-1847.

$\checkmark 5 \mathrm{Kao} \mathrm{JH}$, Chen PJ, Lai MY, Chen DS: Hepatitis $B$ genotypes correlate with clinical outcomes in patients with chronic hepatitis B. Gastroenterology 2000;118:554-559.

-6 Sung JJ, Tsui SK, Tse CH, Ng EY, Leung KS, Lee KH, Mok TS, Bartholomeusz A, Au TC, Tsoi KK, Locarnini S, Chan HL: Genotypespecific genomic markers associated with primary hepatomas, based on complete genomic sequencing of hepatitis B virus. J Virol 2008;82:3604-3611.
7 Tseng TC, Liu CJ, Chen PJ, Lai MY, Lin CL, Kao JH, Chen DS: Subgenotypes of hepatitis $B$ virus genotype $C$ do not correlate with disease progression of chronic hepatitis B in Taiwan. Liver Int 2007;27:983-988.

8 Chan HL, Tse CH, Mo F, Koh J, Wong VW, Wong GL, Lam Chan S, Yeo W, Sung JJ, Mok TS: High viral load and hepatitis B virus subgenotype Ce are associated with increased risk of hepatocellular carcinoma. J Clin Oncol 2008;26:177-182.

-9 Kim H, Jee YM, Song BC, Shin JW, Yang SH, Mun HS, Kim HJ, Oh EJ, Yoon JH, Kim YJ, Lee HS, Hwang ES, Cha CY, Kook YH, Kim $\mathrm{BJ}$ : Molecular epidemiology of hepatitis B virus (HBV) genotypes and serotypes in patients with chronic HBV infection in Korea. Intervirology 2007;50:52-57.

10 Lee JM, Ahn SH, Chang HY, Shin JE, Kim DY, Sim MK, Hong SP, Chung HJ, Kim SO, Han KH, Chon CY, Moon YM: Reappraisal of HBV genotypes and clinical significance in Koreans using MALDI-TOF mass spectrometry. Korean J Hepatol 2004; 10:260270.

-11 Kim JK, Chang HY, Lee JM, Baatarkhuu O, Yoon YJ, Park JY, Kim DY, Han KH, Chon CY, Ahn SH: Specific mutations in the enhancer II/core promoter/precore regions of hepatitis B virus subgenotype C2 in Korean patients with hepatocellular carcinoma. J Med Virol 2009;81:1002-1008.
12 Sung FY, Jung CM, Wu CF, Lin CL, Liu CJ, Liaw YF, Tsai KS, Yu MW: Hepatitis B virus core variants modify natural course of viral infection and hepatocellular carcinoma progression. Gastroenterology 2009; 137:16871697.

13 Ehata T, Omata M, Chuang WL, Yokosuka O, Ito Y, Hosoda K, Ohto M: Mutations in core nucleotide sequence of hepatitis B virus correlate with fulminant and severe hepatitis. J Clin Invest 1993;91:1206-1213.

14 Okumura A, Takayanagi M, Aiyama T, Iwata K, Wakita T, Ishikawa T, Yoshioka K, Kaku$\mathrm{mu}$ S: Serial analysis of hepatitis B virus core nucleotide sequence of patients with acute exacerbation during chronic infection. J Med Virol 1996;49:103-109.

15 Akarca US, Lok AS: Naturally occurring hepatitis B virus core gene mutations. Hepatology 1995;22:50-60.

16 Lusida MI, Nugrahaputra VE, Soetjipto, Handajani R, Nagano-Fujii M, Sasayama M, Utsumi T, Hotta H: Novel subgenotypes of hepatitis $\mathrm{B}$ virus genotypes $\mathrm{C}$ and $\mathrm{D}$ in $\mathrm{Pa}$ pua, Indonesia. J Clin Microbiol 2008;46: 2160-2166.

17 Chan HL, Tsui SK, Tse CH, Ng EY, Au TC, Yuen L, Bartholomeusz A, Leung KS, Lee $\mathrm{KH}$, Locarnini S, Sung JJ: Epidemiological and virological characteristics of 2 subgroups of hepatitis B virus genotype C. J Infect Dis 2005; 191:2022-2032. 
18 Rho HM, Kim K, Hyun SW, Kim YS: The nucleotide sequence and reading frames of a mutant hepatitis B virus subtype adr. Nucleic Acids Res 1989;17:2124.

-19 Cavinta L, Sun J, May A, Yin J, von Meltzer M, Radtke M, Barzaga NG, Cao G, Schaefer S: A new isolate of hepatitis B virus from the Philippines possibly representing a new subgenotype C6. J Med Virol 2009;81:983-987.

20 Sugauchi F, Orito E, Ichida T, Kato H, Sakugawa H, Kakumu S, Ishida T, Chutaputti A, Lai CL, Ueda R, Miyakawa Y, Mizokami M: Hepatitis B virus of genotype B with or without recombination with genotype $C$ over the precore region plus the core gene. J Virol 2002;76:5985-5992.
21 Chan HL, Wong ML, Hui AY, Hung LC, Chan FK, Sung JJ: Hepatitis B virus genotype $\mathrm{C}$ takes a more aggressive disease course than hepatitis $B$ virus genotype $B$ in hepatitis $\mathrm{B}$ e antigen-positive patients. J Clin Microbiol 2003;41:1277-1279.

22 Enomoto M, Tamori A, Nishiguchi S: Hepatitis $\mathrm{B}$ virus genotypes and response to antiviral therapy. Clin Lab 2006;52:43-47.

23 Jang JW, Lee YC, Kim MS, Lee SY, Bae SH, Choi JY, Yoon SK: A 13-year longitudinal study of the impact of double mutations in the core promoter region of hepatitis B virus on $\mathrm{HBeAg}$ seroconversion and disease progression in patients with genotype $\mathrm{C}$ chronic active hepatitis. J Viral Hepat 2007;14:169175.

24 Wang Z, Tanaka Y, Huang Y, Kurbanov F, Chen J, Zeng G, Zhou B, Mizokami M, Hou $\mathrm{J}$ : Clinical and virological characteristics of hepatitis $\mathrm{B}$ virus subgenotypes $\mathrm{Ba}, \mathrm{C} 1$, and C2 in China. J Clin Microbiol 2007;45:14911496.
25 Yuan J, Zhou B, Tanaka Y, Kurbanov F, Orito E, Gong Z, Xu L, Lu J, Jiang X, Lai W, Mizokami M: Hepatitis B virus (HBV) genotypes/ subgenotypes in China: mutations in core promoter and precore/core and their clinical implications. J Clin Virol 2007;39:87-93.

26 Mondelli M, Vergani GM, Alberti A, Vergani D, Portmann B, Eddleston AL, Williams R: Specificity of T lymphocyte cytotoxicity to autologous hepatocytes in chronic hepatitis $B$ virus infection: evidence that $T$ cells are directed against HBV core antigen expressed on hepatocytes. J Immunol 1982;129:27732778. 